\title{
GATM wt Allele
}

National Cancer Institute

\section{Source}

National Cancer Institute. GATM wt Allele. NCI Thesaurus. Code C122897.

Human GAT M wild-type allele is located in the vicinity of 15q21.1 and is approximately 41 $\mathrm{kb}$ in length. This allele, which encodes glycine amidinotransferase, mitochondrial protein, is involved in the synthesis of creatine from L-arginine and glycine. 